\title{
The "Indo-Pacific": Intellectual Origins and International Visions in Global Contexts
}

\author{
Hansong $\mathrm{Li}^{\star}$ (id \\ Department of Government, Harvard University \\ *Corresponding author. E-mail: hansongli@fas.harvard.edu
}

(Received 20 August 2020; revised 19 October 2020; accepted 16 April 2021)

\begin{abstract}
As the "Indo-Pacific" concept gains currency in public discourses on foreign policy, it remains poorly understood as an idea, due to inadequate surveys of its intellectual origins and international visions in global contexts. This article studies Karl Haushofer's theory of the "Indo-Pacific" as an organic and integral space primed for political consciousness. Haushofer not only laid the oceanographic foundation of the "Indo-Pacific" with novel evidence in marine sciences, ethnography, and philology, but also legitimated it as a social and political space. Mindful of Germany's geopolitical predicament in the interwar period and informed by sources in indology and sinology, Haushofer envisaged the political resurrection of South, East, and Southeast Asia against colonial domination, and conceived the "Indo-Pacific" vision for remaking the international order.
\end{abstract}

\section{Introduction}

This paper studies the historical "Indo-Pacific" theory in its academic and political contexts. It traces this concept of oceanic space to the innovations of the German geographer Karl Haushofer (1869-1946). At a time when modern natural and social scientists uncovered new evidence on alternative shapes of the world map, Haushofer politicized oceanography, ethnography, and philology to realign the Indian and Pacific Oceans as an integral space. The purpose of his intervention, however, was to forge an anticolonial vision in British, American, and Western European colonies in South, East, and Southeast Asia, and thus undermine the Western rivals of interwar Germany. By recovering Haushofer's political oceanography and anticolonial vision in the original "Indo-Pacific," scholars not only gain an important episode in the modern intellectual history of politicizing spaces, but also acquire a stimulating language to question what the contemporary "Indo-Pacific" discourse misses: the legacy of colonial and anticolonial politics along the fault lines of natural and social spaces.

In this survey of political thought and intellectual history, I aim to bridge a significant gap between the popular geopolitical reception and the scant theoretical exposition of the "Indo-Pacific" concept. Of late, the term has gained currency

(c) The Author(s), 2021. Published by Cambridge University Press. This is an Open Access article, distributed under the terms of the Creative Commons Attribution licence (http://creativecommons.org/licenses/by/4.0/), which permits unrestricted re-use, distribution, and reproduction in any medium, provided the original work is properly cited. 
amongst observers and practitioners of foreign policy. Shinzo Abe referred to the integration of the Indian and Pacific Seas in his 2007 "Confluence of the Two Seas" address to the Parliament of India, and his 2016 "Toward a Free and Open Indo-Pacific" speech in Kenya. Two years later, the United States responded by renaming its "Pacific Command" the "Indo-Pacific Command." These rhetorical moves, however, have not yet provoked any serious academic discussion of the genesis, structure, and evolution of the "Indo-Pacific" concept. In academic circles, political scientists rely on secondary scholarship to trace the origin of the "Indo-Pacific" to the Weimar Republic, but they fall short of explaining what the "Indo-Pacific" really was in its early formulations. ${ }^{2}$ As a result, the past of the "Indo-Pacific" remains a dull fact without substance. Historians, on the other hand, draw on richer sources to explore Haushofer's intellectual legacy in German and Japanese geopolitical thought. In particular, recent scholarship seeks to uncover the confluence of German space theories and pan-Asianist ideas. ${ }^{3}$ Even so, no focused exposition of Haushofer's "Indo-Pacific" is yet available. Furthermore, historians have paid attention to Japan but neglected Haushofer's larger vision for the Indian and Pacific Oceans, especially India and China. As a result, the idea of a resurrected "Indo-Pacific" comprising anticolonial forces in India, China, and Southeast Asia remains unexplored. Overall, whereas contemporary commentaries suffer from an exiguous understanding of Haushofer's spatial theory, historians have yet to intervene to unravel the intellectual origins of the "Indo-Pacific."

\footnotetext{
${ }^{1}$ Shinzo Abe, "Confluence of the Two Seas: Speech by H.E. Mr. Shinzo Abe, Prime Minister of Japan at the Parliament of the Republic of India” (二つの海の交わり:インド国会における安倍総理大臣演説), Ministry of Foreign Affairs of Japan, New Delhi, India, 22 Aug. 2007. Abe appropriates Swami Vivekananda's line, "the different streams, having their sources in different places, all mingle their water in the sea," in Swami Vivekananda, Complete Works, with an Index (Almora, 1915), p. 2; "Addresses at the Parliament of Religions, Chicago 11th September, 1893." The rest of the quote is: "so, O Lord, the different paths which men take through different tendencies, various they they appear, crooked or straight, all lead to thee." "Address by Prime Minister Shinzo Abe at the Opening Session of the Sixth Tokyo International Conference on African Development” (TICAD VI 開会に当たって・安倍晋三日本国総 理大臣基調演説), Ministry of Foreign Affairs of Japan, Nairobi, Kenya, 27 Aug. 2016. Department of Defence of the Australian Government, Defence White Paper (Canberra, 2013), passim. United States Department of State, A Free and Open Indo-Pacific: Advancing a Shared Vision (Washington, DC, 4 Nov. 2019).

${ }^{2}$ Gurpreet S. Khurana, "Security of Sea Lines: Prospects for India-Japan Cooperation," Strategic Analysis 31/1 (2007), 139-53; Teruaki Aizawa et al., eds., Kaiyō anzen hoshō jōhō kihō 海洋安全保障情報季報 (From the Ocean) 13 (2016); Timothy Doyle and Dennis Rumley, The Rise and Return of the Indo-Pacific (Oxford, 2020), 29, 33-4, 39, 43. Doyle and Rumley's contribution is long overdue and much welcome, and yet disappointing, from the inversion of Xi Jinping's first and last names at 147, 150, 193, to their excessive reliance on outdated Haushofer scholarship-notably A. Dorpalen, The World of General Haushofer (New York, 1942) - and outright inaccurate interpretations of Haushofer, e.g. H. Herwig, The Demon of Geopolitics (Lanham, 2016) at 29-30. See also Christian W. Spang, "The Demon of Geopolitics: How Karl Haushofer 'Educated' Hitler and Hess by Holger H. Herwig," Central European History 52/3 (2019), 542-4.

${ }^{3}$ Akihiko Takagi, "Japanese Nationalism and Geographical Thought," Geopolitics 3/3 (1998), 125-39; Keiichi Takeuchi, "Japanese Geopolitics in the 1930s and 1940s," in K. Dodds and D. Atkinson, eds., Geopolitical Traditions (London, 2000), 72-92. Christian W. Spang, Karl Haushofer und Japan (Munich, 2013).
} 
To understand the texture and structure of the original "Indo-Pacific" theory, it is necessary to consider the social, political, and intellectual contexts of Karl Haushofer. Born in Munich the eldest son of economist Max Haushofer Jr, Haushofer received a Gymnasium education and served the Bavarian Army in the late 1880s. After training and teaching at the Bavarian War Academy, he undertook a global journey that changed the trajectory of his career. Urged and assisted by his activist wife Martha Haushofer, he served as a military observer in Japan from February 1909 to June $1910 .{ }^{4}$ On his journey to the East, Haushofer also eyewitnessed the social and political situations in British India, Ceylon, Singapore, and Hong Kong. Upon his return, Haushofer embarked on political-geographic studies, first on Japan, then broadly on global geopolitics. And upon his retirement as major general in the pivotal year of 1919, Haushofer met Rudolph Hess and, through him, Adolf Hitler. In spite of the slim link between Haushofer's theories and Nazi foreign policies, Haushofer is today remembered chiefly for his controversial associations with the Third Reich, as well as his son Albrecht's involvement in the 20 July plot to assassinate the Führer. In the 1920s-1930s, however, Haushofer tried to be both a patriotic strategist and an international visionary. And it is this Haushofer that sought to integrate the Indian and Pacific Oceans to galvanize Asian anticolonialism as a maritime route out of Germany's geopolitical predicament.

Indeed, Haushofer's "Indo-Pacific" theory emerged and matured in the 1920s1930s, as a prescription for Germany and a vision for world politics, prior to the formation of the Third Reich's foreign policy. Haushofer presented a fully fledged, if not systematic, idea of the "Indo-Pacific" in the Geopolitics of the Pacific Ocean. The concept reappeared in the Building Blocks of Geopolitics, Geopolitics of Pan-Ideas, and German Cultural Politics in the Indo-Pacific Space. ${ }^{5}$ In this paper, I reconstruct Haushofer's own account of the "Indo-Pacific" concept in his major treatises on political oceanography, especially the Pacific Ocean. The subtitle of the 1924 text-"studies on the interrelations between geography and history"bespeaks Haushofer's method and purpose. Haushofer aimed to offer an alternative account of historical patterns grounded in political geography and oceanography rather than artificial borders based on historically contingent divisions of norms, religions, and institutions. As his paeans to Georg Forster, Georg Christoph Lichtenberg, and Alexander von Humboldt in both Pacific Ocean and Indo-Pacific Space make clear, Haushofer placed himself forthright into the tradition of "geo-historical" thought on customs and mores from early modern natural jurisprudence that ran from the Enlightenment to nineteenth-century German political theory. ${ }^{6}$

\footnotetext{
${ }^{4}$ Spang, Karl Haushofer und Japan, 92; Christian Spang, "How Reliable Is Wikipedia 18 Years after Its Establishment? A Comparative Look at Various Language Entries on Karl Haushofer," Outside the Box: A Multi-lingual Forum 9/1 (2019) 35-47, at 35.

${ }^{5}$ Karl Haushofer, Geopolitik des Pazifischen Ozeans: Studien über die Wechselbeziehungen zwischen Geographie und Geschichte: Mit sechzehn Karten und Tafeln (Berlin, 1924); Haushofer, "Geopolotik und Kaufmann," in Karl Haushofer, Erich Obst, Hermann Lautensach, and Otto Maull, eds., Bausteine zur Geopolitik (Berlin-Grunewald, 1928), 270-85, at 281-2; trans. Hajime Tamaki (玉城肇), Chi seiji manabu no kiso ri 地政治學の基礎理論 (Tokyo, 1941). Karl Haushofer, Geopolitik der Pan-Ideen (Berlin, 1931); Haushofer, Deutsche Kulturpolitik im indopazifischen Raum (Hamburg, 1939).

${ }^{6}$ Haushofer, Geopolitik des Pazifischen Ozeans, 10; Haushofer, Deutsche Kulturpolitik im indopazifischen Raum, 22, Appendix, Figures 5, 11; Isaac Nakhimovsky, The Closed Commercial State (Princeton, 2011);
} 
Haushofer considered Germany's "Middle European" geography, in contrast to the "Atlantic and the Pacific," a major impediment to political growth. ${ }^{7}$ Of course, the anxiety over a landlocked geography unfavourable to global commerce is a recurring motif in modern German political thought. But Haushofer's ambition was to offer a novel theorization of this historical concern, hence a new answer to the old question. In this sense, he constructed the "Indo-Pacific" theory in search of a place for landlocked Germany in the maritime space between states. Yet Haushofer's "Indo-Pacific" theory went beyond the Weimar political agenda to call for a global anticolonial vision. Eager to build an international "Indo-Pacific" strategy, Haushofer sailed to broader temporal and spatial horizons. He not only legitimated the spatial integration of the Indian and Pacific Oceans in virtue of their oceanographical linkage, but argued that the "Indo-Pacific" space was primed for political selfconsciousness, especially in the light of nascent anticolonial movements. Accordingly, the political resurrection of nations along the "Indo-Pacific" maritime belt would subvert Anglo-American and Western European colonial domination, and in this way remake the international order.

Haushofer endowed significant normative force in the "Indo-Pacific" as he leveraged the concept for an anticolonial vision. Thus I argue that the "Indo-Pacific" is a substantive theory, whereas a more notorious concept such as Lebensraum remains largely rhetorical in Haushofer's political thought. At the same time, the ambition of the "Indo-Pacific" vision compelled Haushofer to expand his sources and upgrade his methods. Consequently, Haushofer deployed a rich layer and a wide array of evidence in oceanography, historical philology, and ethnography to make the case for the "Indo-Pacific" as one natural, social, and political space.

\section{The political oceanography of the "Indo-Pacific"}

The first step to recover and rethink Haushofer's "Indo-Pacific" is to examine the architecture of his political oceanography. To preempt the charge of artifice and arbitrariness against the invention of the neologism "Indo-Pacific," Haushofer forewarned his critics that the union of the Indian and Pacific Oceans is more natural than their separation. He insisted that, in fact, it is the natural "Indo-Pacific" world that had been carved up by artificial and arbitrary borders. Of course, Haushofer, too, divided the global oceanic space. For instance, he defined the European Atlantic and the "Indo-Pacific" as natural "counterspaces." But what he meant by this term is not merely an "oceanic counterspace of a landmass separated

David Armitage, "The International Turn in Intellectual History," in D. M. McMahon and S. Moyn, eds., Rethinking Modern European Intellectual History (New York, 2014), 232-52; John Randolph, "The Space of Intellect and the Intellect of Space," in ibid., 212-31; Lauren Benton, A Search for Sovereignty: Law and Geography in European Empires, 1400-1900 (Cambridge, 2009); Annabel S. Brett, "The Space of Politics and the Space of War in Hugo Grotius's De iure belli ac pacis," Global Intellectual History 1/1 (2016), 33-60; Hansong Li, "The Space of the Sea in Montesquieu's Political Thought," Global Intellectual History (2018), DOI: 10.1080/23801883.2018.1527184; Jennifer Pitts, Boundaries of the International (Cambridge, MA, 2018). More recently and closely related, Joshua Derman, "Prophet of a Partitioned World: Ferdinand Fried, 'Great Spaces,' and the Dialectics of Deglobalization, 1929-1950," Modern Intellectual History (2020), DOI: 10.1017/S1479244320000190.

${ }^{7}$ Haushofer, "Geopolotik und Kaufmann," 283. Haushofer believed that geo-oceano-politics might loosen the constraint on commerce in Middle Europe. 
only by a meridional ditch." ${ }^{8}$ Rather, he sought to demonstrate what a space should have been on the grounds of marine-biological and oceanographic evidence. In this case, "animal geography" (Tiergeographie) naturally separates the "Indo-Pacific" and the Atlantic oceans, whereas one continuous "life unit" (Lebenseinheit) spans the Indian and Pacific regions. ${ }^{9}$ That is why an artificial "Indo-Atlantic" space-even if it were forced upon the natural "Indo-Pacific" space by British, American, and European colonial powers-cannot last long. ${ }^{10}$ In this way, Haushofer leveraged the oneness of animal life to legitimate the reintegration of historically dispersed human life. The underlying theme is to redeem and restore nature: "animal geography" - the routes of fishes swimming from Madagascar to the Austroasiatic coasts-have more to teach political societies than international treaties. Later in Geopolitics of Pan-Ideas, Haushofer offered a historico-anthropological argument in support of the "animal-geography" thesis. He suggested that, at first, humans were all inclined to pacify their individual seas. ${ }^{11}$ Over time, societies legitimated the sociopolitical division of the sea through customs. Reversely, the redemarcation of the seas was a distinctly modern project. For it was then possible, in the age of modern oceanography, to reconstruct the original maritime space and reimagine the political lives of earlier, even earliest, times. In short, Haushofer placed the temporal priority and logical necessity of the modern "Indo-Pacific" in its continuity and antiquity.

After laying the natural foundation of the "Indo-Pacific" space, Haushofer deployed further oceanographic evidence to make it a social space. Crucially, Haushofer designated the "Indo-Pacific" a bounded "life realm" (Ökumene), and separated it from the "no-life realm" (Anökumene). He divided the two spaces along the "southern borders" set naturally by the permanent "good west winds" in the southern seas and the oceanic currents of Antarctica. ${ }^{12}$ According to Haushofer, these demarcations of the "purely oceanic dreamland of the southern border zone" are "more acceptable from a physical point of view," precisely because the winds and currents also determine the operations of human activities: sailing, steamship, and fleet routes, which in turn shape the contours of power in international politics. ${ }^{13}$

\footnotetext{
${ }^{8}$ Haushofer, Geopolitik des Pazifischen Ozeans, Ch. 2 ("Raumbild des Grossen Ozeans nach Flächen, Grenzen und Lage"), 35: "so sehen wir den Gegenraum Europas, nicht nur den ozeanisch bestimmten Gegenraum einer nur durch einen meridionalen Graben getrennten Landmasse, mit dem Indischen Ozean zusammen eine in manchem verwandte Lebenseinheit bilden, wie ja auch der pazifische Küstentyp durch die Sundasee und das australasiatische Mittelmeer hinüber in den indischen Ozean greift, wie auch die Tiergeographie ein indo-pazifisches Verbreitungsgebiet dem atlantischen gegenüberstellt."

9Ibid. See also Haushofer, "Geopolotik und Kaufmann," 276. Across his multiple works, Haushofer defines the "Indo-Pacific" as a whole against the "Atlantic" or "Eur-Amerika."

${ }^{10}$ Haushofer, Geopolitik des Pazifischen Ozeans, 161.

${ }^{11}$ Haushofer, Geopolitik der Pan-Ideen, 53.

${ }^{12}$ Haushofer's many oceanographic sources will be explored below. Here, note that Haushofer was a colleague of the great explorer of Antarctica Erich von Drygalski (1865-1949) at LudwigMaximilians-Universität München. Haushofer joined the faculty in 1921. Drygalski tought at Munich from 1906 until his death. During his tenure, his explorations also expanded to Spitsbergen, North America, and Asia.

${ }^{13}$ Haushofer, Geopolitik des Pazifischen Ozeans, Ch. 13 ("Südseerand und Australasia"), 181: "Das wären glaubhaftere Grenzen für die politische Ozeanographie, aus der physischen heraus eher annehmbar, weil mit großen Segel-, Dampferund Flottenwegen, also mit Machtlinien zusammenfallend."
} 
It is worth noting that Haushofer deliberately chose the Greek-derived term

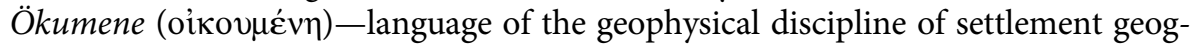
raphy that still remains in use by physical scientists today-over the strictly German Lebensraum-language of the humanistic political geography. No doubt a student of the popularizer of the term Lebensraum Friedrich Ratzel (1844-1904), Haushofer invoked the term throughout his writings. Elsewhere, he spoke not only of the pazifischen Lebensraum and the indischen Lebensraum, but also of the indo-pazifischen Lebensraum and the indopazifisch-ozeanischen Lebensraums. ${ }^{14}$ Nevertheless, Haushofer's Lebensraum falls short of a coherent normative concept. Rather, the word was used loosely to form a motley of expressions. For instance, Haushofer rhetorically referred to the chinesische Lebensraum, even though he clearly believed in no such thing as one single "Chinese living space."15 Therefore I argue that scholars grasp Haushofer's geopolitical thought better if they look beyond the Lebensraum (and its Japanese reception, 生存圏) as the key. ${ }^{16}$ In fact, Haushofer's more ingenious theories of political space have been overshadowed by the notoriety of the Lebensraum. In the past two decades, scholars have laboured to debunk the myth that Haushofer's Lebensraum shaped the foreign policies of the Third Reich and its Japanese ally. ${ }^{17}$ Here, I endorse that argument via a different route, by suggesting that Haushofer used Lebensraum as a generic, indefinite, and even promiscuous term. By contrast, his richer spatial thought lies in grander political visions, such as the "Indo-Pacific."

Haushofer's rhetorical method served the purpose of his intervention: to evoke a normative vision for the global space of international politics. To legitimate his political oceanography, Haushofer sought to mix the terminologies of the geosciences.

\footnotetext{
${ }^{14}$ Haushofer, Geopolitik des Pazifischen Ozeans, 51, 101, 106, 131, 160. For a slightly later invocation of the indopazifischen Lebensraum see Karl Haushofer, "Die Einheit der Monsunländer," in Haushofer et al., Bausteine zur Geopolitik, 106-17, at 106.

${ }^{15}$ Haushofer, Geopolitik des Pazifischen Ozeans, 172. Haushofer's pattern of scattering the word Lebensraum throughout the book is best characterized by his own expression, "von Lebensraum zu Lebensraum."

${ }^{16}$ Charles Kruszewski, “Germany’s Lebensraum," American Political Science Review 34/5 (1940), 964-75; Y. Fukushima, "Japanese Geopolitics and Its Background," Political Geography 16/5 (1997), 407-21. This is by no means to deny the widely known presence of Ratzel's Politische Geographie (Munich and Leipzig, 1897) in Haushofer's thinking; on this old topic see Hans-Dietrich Schultz, "Friedrich Ratzel: Bellizistischer Raumtheoretiker mit Naturgefühl oder Vorläufer der NS-Lebensraumpolitik?", in Claus Deimel, Sebastian Lentz, and Bernhard Streck, eds., Auf der Suche nach Vielfalt: Ethnographie und Geographie in Leipzig (Leipzig, 2009), 125-42; H. Herwig, "Geopolitik: Haushofer, Hitler and Lebensraum," in Colin Gray and Geoffrey Sloan, eds., Geopolitics, Geography and Strategy (London and Portland, 1999), 226-49; Michael Heffernan, "Fin de Siècle, Fin du Monde? On the Origins of European Geopolitics, 1890-1920," in Dodds and Atkinson, Geopolitical Traditions, 27-51; Woodruff D. Smith, "Friedrich Ratzel and the Origins of Lebensraum," German Studies Review 3/1 (1980), 51-68; Harriet Wanklyn, Friedrich Ratzel (Cambridge, 1961), 36-40. Recently, Doyle and Rumley continue to see Haushofer as an extension of Ratzel, in e.g. The Rise and Return of the Indo-Pacific, 9.

${ }^{17}$ The exclusive focus on Lebensraum, from Kruszewski to recent scholars, as Haushofer's spatial thought is misleading. On this point, I endorse the myth-busting Othmar Plöckinger, Geschichte eines Buches: Adolf Hitlers "Mein Kampf" (Munich, 2002), 145; and David T. Murphy, "Hitler's Geostrategist? The Myth of Karl Haushofer and the 'Institut für Geopolitik" (2014), The Historian 76/1 (2020), 1-25, at 16-17, as well as Christian W. Spang, "Revisiting Karl Haushofer at 150: A Critical Look at the Most Recent Biography," Outside the Box: A Multi-lingual Forum 9/1 (2019), 23-34, at 30; and Spang, "How Reliable Is Wikipedia," 36, that Haushofer's Lebensraum influence on Nazism is exaggerated.
} 
Here, the rhetorical force lies in the synthesis of interdisciplinary languages itself. Haushofer's goal was to validate a younger and more controversial concept by marrying it to seemingly more natural and neutral, and certainly older and more authoritative, sister disciplines. ${ }^{18}$ In fact, I will show that Haushofer also turned to historical ethnography and philology to politicize oceanography. Generally speaking, Haushofer employed a wider range of academic evidence than earlier and contemporary political theorists of space. With these tools at hand, Haushofer further politicized the space of the sea by reimagining past political lives and exploiting their potential in his own time.

\section{The sea space as a life space and a political space}

Haushofer framed the "Indo-Pacific" oceanic space as a site for social and political life, both in the past and for the future. Ostensibly, rehabilitating the "Indo-Pacific" mirrors the taming of the Atlantic. So this crude analogy legitimates the politicization of the "Indo-Pacific" by reference to Anglo-American domination across the Atlantic. Haushofer realized, however, that in both cases a critical challenge is the place of the indigenous people in a politicized oceanic space. In response, he recognized indigenous political cultures in the Indian and Pacific regions.

First, Haushofer theorized the indigenous "Indo-Pacific" political life in its antiquity. He reimagined how, in earliest times, the Malayo-Polynesian "wandering peoples" (schweifenden Menschen) "filled in the maritime space like nomads" (den Seeraum als Nomaden erfüllten) from island to island. ${ }^{19}$ Today, the term "Malayo-Polynesian" survives in historical linguistics, but is no longer deemed accurate in ethnography. However, Haushofer's deployment of this term to historicize and politicize the "Indo-Pacific" was built on the most cutting-edge anthropological, oceanographic, and philological research of the time. For it was before and around this period that philologists such as J. C. G. Jonker, Charles Otto Blagden, Renward Brandstetter, Wilhelm Schmidt, and Otto Dempwolff discovered similarities ranging from Polynesian and Oceanic to Pilipino, South Asian, and East African languages. ${ }^{20}$ Whilst oceanographers discovered that an overwhelming

\footnotetext{
${ }^{18}$ Murphy, "Hitler's Geostrategist?" 5, points out Haushofer's marginal status in "Geographie" at Munich, where he lectured on "Wehrwissenschaften." This explains more, not less, Haushofer's effort to build a solid geo-oceanographic foundation for his political theory.

${ }^{19}$ Haushofer, Geopolitik des Pazifischen Ozeans, 11.

${ }^{20}$ J.C.G. Jonker, "Kan men bij de talen van de Indische Archipel eene westelijke en eene oostelijke afdeeling onderscheiden?", VMKAW 4/12 (1914), 314-417. Charles Otto Blagden, Preface, in Renward Brandstetter, An Introduction to Indonesian Linguistics (London, 1916), x-xi; Wilhelm Schmidt, Über das Verhälltniss der melanesischen Sprachen zu den polynesischen und untereinander (Vienna, 1899); Schmidt, "Die sprachlichen Verhältnisse von Deutsch Neuguinea," Zeitschrift für Afrikanische, Ozeanische und Ostasiatische Sprachen 5 (1900), 354-84, 6 (1901), 1-97; Schmidt, Die Mon-Khmer Völker: Ein bindeglied zwischen Völkern Zentralasiens und Austronesiens (Braunschweig, 1906); Schmidt, Die Sprachfamilien und Sprachkreise der Erde (Heidelberg, 1926). Nineteeneth-century scholarship: Georg von der Gabelentz, "Spuren eines ausgebildeten Conjugationssystems im Dayak," Zeitschrift der Deutschen Morgenländischen Gesellschaft 14/3 (1860), 547-9; Gabelentz, "Einiges über das Verhältnis des Mafoor zum Malayischen," in Gabelentz, Bijdragen tot de taal-, land-en volkenkunde: Koninklijk Instituut voor de Taal-, Land-en Volkenkunde van Nederlandsch-Indie (Leiden, 1883), 242-60; Georg von der Gabelentz with Adolf Bernhard Meyer, "Beiträge zur Kenntnis der melanesischen, mikronesischen und papuanischen Sprachen: ein erster Nachtr. zu Hans Conon's von der Gabelentz Werke Die
} 
number of marine species flowed routinely and continuously between Madagascar and the Pacific islands, ${ }^{21}$ linguists found that the borders of the Austronesian language subgroup turn out to be Malagasy in the west, and Fijian-Polynesian in the east. In both oceanography and philology, therefore, there emerged a gradual consensus that the "South Seas" as a holistic maritime space provides the explanatory framework for large-scale changes beyond the farthest inklings of human civilization. Note also that the now-outdated term Südsee was politicized and popularized during the 1919 Paris Peace Conference, where the "South Sea Mandate" redistributed German possessions in the Pacific to Japan, Australia, and New Zealand. ${ }^{22}$ So discontent with recent maritime dispossessions was another salient context to interwar German discourses on the "South Seas." Therefore, although Haushofer included in this maritime space also the Maya and Inca cultures, he focused on the "sea nomads" as the prototypical "Indo-Pacific" form of life.

Haushofer's concept of "sea nomads" is eerily reminiscent of Carl Schmitt's later designation of hostile maritime nations as "fishmen," but it is important to tell them apart. To Schmitt's "fishmen" the time and space on land seem "strange and incomprehensible." ${ }^{23}$ Such an idea is strictly in line with the "land-versus-sea" trope in Anglo-German thought since at least the sixteenth century. Already in Der Weisskunig, the Hapsburg Empire is ruled by the old and new "White Kings"

melanesischen Sprachen," Abhandlungen der Philologisch-Historischen Klasse der Königlich-Sächsischen Gesellschaft der Wissenschaften Leipzig 8/4 (1882), 380-541; Franz Bopp, Über die Verwandtschaft der malaiisch-polynesischen Sprachen mit dem Indogermanischen (Berlin, 1841). Bopp is influenced by his family's experience in the chaotic Republic of Mainz, a historical memory of the Prussian Enlightenment.

${ }^{21}$ Otto Krümmel, Handbuch der Ozeanographie, 2 vols. (Stuttgart, 1907-11). He speaks of not only "Bereiche des ganzen Pazifischen und Indischen Ozeans (mit Ausnahme der höchsten Breiten)" but also "die südatlantisch-indischen" etc. at 480; see also 489, 610, 720. Krümmel's completion of Heinrich Georg von Boguslawski's Handbuch der ozeanographie (1884-7) and his succession to geographer Theobald Fischer were important to German oceanography, as it lagged behind that of Britain, sponsor of the 1872-6 Challenger expedition, which yielded insights on the global maritime distribution of coral reefs, key evidence on Indo-Pacific continuity. Contemporary research continues to confirm the importance of the Indo-Pacific juncture as a whole to marine biodiversity, e.g. P. de Deckker, "The Indo-Pacific Warm Pool," Geoscience Letters 3/20 (2016), 1-12; M. R. Gaither et al., "Phylogeography of the Reef Fish Cephalopholis argus (Epinephelidae) Indicates Pleistocene Isolation across the Indo-pacific Barrier with Contemporary Overlap in the Coral Triangle," BMC Evolutionary Biology 11/189 (2011), 1-15; E. Maire et al., "Community-Wide Scan Identifies Fish Species Associated with Coral Reef Services across the Indo-Pacific," Proceedings of the Royal Society B285 (2018), 1-9.

${ }^{22}$ Mark Peattie, Nan'yō: The Rise and Fall of the Japanese in Micronesia, 1885-1914 (Honolulu, 1988), xvii-xviii; 52-61; 67-70, 77-118, and passim; Ramon H. Myers and Mark R. Peattie eds., The Japanese Colonial Empire, 1895-1945 (Princeton, 1984); Alison Bashford, "Karl Haushofer's Geopolitics of the Pacific Ocean," in Kate Fullagar, ed., The Atlantic World in the Antipodes: Effects and Transformations since the Eighteenth Century (Newcastle, 2012), 120-43, at 120.

${ }^{23}$ Haushofer, Geopolitik des Pazifischen Ozeans, 131, 159-60, 171-3, 181. Carl Schmitt, Land und Meer: Eine weltgeschichtliche Betrachtung (Stuttgart, 2008; first published 1942), 10; on the Fischmenschen concept see Andreas Oberprantacher, "Phantome zwischen uns: Einem ominösen Phänomen namens 'Illegale' auf der visuellen Spur," in Artur R. Boelderl and Monika Leisch-Kiesl, eds., Die Zukunft gehört den Phantomen: Kunst und Politik nach Derrida (Düsseldorf, 2018), 227-52; Jürgen Stillig, Heilige Berge: Exzellenz-Entzauberung-Absurdität, vol. 1 (Hildesheim, 2018); Richard Reschika, Meer, du berührst meine Seele (Gütersloh, 2012), 56-7. See Schmitt's South Sea nomads in Land und Meer, 10: "Auf den Inseln der Südsee, bei polynesischen Seefahrern, Kanaken und Sawoiori, erkennt man noch die letzten Reste solcher Fischmenschen. Ihr ganzes Dasein, ihre Vorstellungswelt und Sprache war meerbezogen." 
(Frederick III and Maximilian I), France by an aquatic "Blue King," and Venice by a thoroughly maritime "King of Fish." There, the terrestrial "White King" is portrayed as antagonistic and superior to the "fishmen," capturing many cities of the King of Fish largely unopposed. ${ }^{24}$ This "terrestrial-versus-maritime" dichotomy, along with the "Behemoth-versus-Leviathan" allegory, forms a tradition of representing land and sea powers in Western political and literary languages. In Schmitt's time, Lord Salisbury reminded the German ambassador and Queen Victoria, "We are fish"; ${ }^{25}$ in 1922, T. S. Eliot alluded to the "fishmen" as an amphibious hybrid metaphor for "Englishness," possibly inspired by Shakespeare's Caliban. ${ }^{26}$ The reimagination of nations as land and sea creatures acquired increasing salience from early modern to modern Europe, in the fluid contexts of overseas colonial expansion and global naval rivalry. In this light, it is Schmitt's European "fishmen," not Haushofer's indigenous "sea nomads," that explicitly evokes this discourse.

Well versed in the "land-and-sea" historiography, Haushofer was no stranger to allegorizing maritime powers as alien creatures. However, mindful of his own purpose of politicizing the maritime space from within the "Indo-Pacific," Haushofer offered a "Herodotian" rationalization of maritime politics: that by virtue of their "virile nobility," indigenous leaders eschewed political corruptions inherent to a settled "stately form of life." Arguably, Haushofer was reimagining maritime nomadic politics through popular narratives of terrestrial nomadic cultures. After all, in addition to the "Blue King" and the "Fish King," the "White King" was also concerned with a "Green King" of the steppe-Hungary. And given Haushofer's own interest in Eurasian geopolitics, he might have transplanted terrestrial visions, such as the "Indo-Serian" Silk Road, onto the "Indo-Pacific" ocean. ${ }^{27}$ Regardless, rather than style Germany's rivals as sea monsters, Haushofer sought to legitimate indigenous political lives on the sea, in order to shake the colonial dominions of adversarial powers. For this reason, Haushofer conceived terrestrial and maritime powers as cognate counterparts, not as irreconcilable antagonists. ${ }^{28}$

\footnotetext{
${ }^{24}$ Maximilian I, Weisskunig, ed. Marx Treitz-Saurwein, Hans Burgkmair and H. Theodor Musper (Stuttgart, 1956), Ch. 157, e.g. "als der blaue König mit dem König von Fisch Krieg führte, da entschloss sich auch der Weisskunig einzugreifen; nach der Niederlage des Königs vom Fisch gegen den blauen König, konnte der Weisskunig ohne große Gegenwehr viele Städte des Königs vom Fisch einnehmen.” See Johannes Helmrath, Ursula Kocher, and Andrea Sieber, eds., Maximilians Welt (Göttingen, 2018).

${ }^{25}$ "Nous sommes des poissons." Auswärtiges Amt, Die grosse Politik der europäischen Kabinette, 18711914, 53 vols. (Berlin, 1922-7), 4: 265; trans. E. T. S. Dugdale et al., German Diplomatic Documents 18711914, with a Preface by Rt. Hon. Sir Rennell Rodd and an Introduction by J. W. Headlam-Morley, 4 vols. (London, 1928-31) 1: 249; Robert K. Massie, Dreadnought: Britain, Germany, and the Coming of the Great War (New York and Toronto, 1991), 201.

${ }^{26}$ T. S. Eliot, The Waste Land (New York, 1922), 263; William Shakespeare, The Tempest, 2.2.25-37.

${ }^{27}$ See discussion on the "Indo-Serian" below.

${ }^{28}$ In contrast to Schmitt, Haushofer synthesizes land and sea perspectives. The idea that Haushofer preaches the irreconciliable opposition between terrestrial and maritime political cultures is erroneous. Dorpalen, for example, imagines that Haushofer believes in "an eternal conflict between land-locked continental peoples which are trying to advance onto and across the sea, and seafaring oceanic ones who strive to broaden their hold on the land." This view comes closer to Schmitt's, but even Schmitt's view is much less mechanical. See Dorpalen, The World of General Haushofer, 17-18.
} 


\section{The pivotal space of the "Indo-Pacific"}

Once Haushofer had established the "Indo-Pacific" way of life, he tried to locate a core area of the oceanic space as its own "Mediterranean." To this end, he zoomed in on a key subspace of the "Indo-Pacific": the area between the "Sunda Sea" and the "Australasian Mediterranean," which connects the Pacific coasts to the Indian Ocean. Here it is worth noting that the "Australasian Mediterranean" remains in academic use today, whereas the "Sunda Sea" is no longer referred to as a sea proper. ${ }^{29}$ The "Sunda Shelf," or simply the "Sunda," with its encompassing straits and Pleistocene undersea river systems, was an ideal talking point for Haushofer, given its mysterious status as a half-buried block of land. ${ }^{30}$ The vivid scene of Paleolithic inland waterways now floating underneath the ocean-waters within water-blurs the line between land, shelf and sea, continent and archipelago, freshwater and saltwater, as alternative spaces for political life. But Haushofer insisted on the Sunda being a sea, not merely a shelf, mainly to preserve the unity of the "Indo-Pacific." Situated between Java and Sumatra, the Sunda Strait links the Western Pacific and the Indian Oceans. Once the knot that binds the "Indo-Pacific" together was established as both a "former land" and "current sea," this "other Mediterranean" allowed Haushofer to move back and forth between these two definitions, make expedient arguments backed up by oceanographic evidence, and fend off objections from different angles. After all, if the Sunda were a threefold "sea within a Mediterranean within an Ocean," impossible to disentangle from within, it would be absurd to separate the two vast waters to its west and east-the Indian and Pacific Oceans. Again, the logical end point of this "Australasian Mediterranean" thought experiment is the unity of the "Indo-Pacific."

Haushofer's project to turn the Sunda into the pivotal space of the "Indo-Pacific" again showcases his politicization of oceanography. At first glance, Haushofer's knowledge in the Sunda Strait seems largely consistent with Otto Krümmel's analysis of the "Sunda region" (Sundagebiet) and "Sunda pathway" (Sundastraße) in his Handbook of Oceanography (1910). The great German oceanographer saw the Sunda Strait as a key maritime crossroad between the Indian and Pacific Oceans, and an opening to the South China Sea. But Haushofer took a step further to historicize and theorize the Sunda as a site of political life. "Purely physical demarcation is not enough," he pronounced; "here the stately forms of life must be questioned about their inherent will to belong, if geopolitically stable design elements are to be created." ${ }^{31}$ Thus Haushofer not only recognized the Sunda Strait as an oceanic pathway, but also interrogated its political potential.

\footnotetext{
${ }^{29}$ Haushofer, Geopolitik des Pazifischen Ozeans, 35, 161.

${ }^{30}$ Sunda possibly derives from सुन्द (prefix सु, PIE ${ }^{\star} h_{1} s u$-, name of either Viṣnu, a monkey, or a son of Nisunda who killed his brother Upasunda over the beautiful Apsara Tilottama; see Mahabharata, I.211). The Sunda Kingdom, loosely associated with western Java, proliferated in late medieval and early modern geographical references, up to European maritime encounters in the region. Paleogeographers refer to "Sundaland" as the region exposed above sea level throughout the last 2.6 million years. In anthropology, the biogeographic term "Sunda" has been used to account for the ethnogenesis of the "Sundanese" people. Sunda-related compounds abound in German geography: den Sundagraben, die Sundasee, die Sundainseln (Indonesian archipelago, including Große Sundainseln and Kleine Sundainseln), den Sundabogen, etc. But the term Sundasee is almost completely out of fashion.

${ }^{31}$ Haushofer, Geopolitik des Pazifischen Ozeans, 181.
} 
Although, by present-day standards, Haushofer may be accused of misconstruing and mythologizing the "Sunda Sea," his intuition on Sunda's enduring strategic significance was prescient. Since the 1940s, the Sunda Strait has been a recurring geopolitical flashpoint. Three years after the publication of Indo-Pacific Space, this pivotal space was contended in the Battle of Sunda Strait (1942), where Rear Admiral Kenzaburo Hara's amphibious force sank allied cruisers HMAS Perth and USS Houston. More recently, international eyes returned to the same space when Joko Widodo gestured to shelve the plan of the China Railway Construction Corporation (CRCC) to build a bridge across the Sunda. ${ }^{32}$ In the context of Weimar political thought, Haushofer's ambition was to undermine Western colonial powers without sparking another world war. Thus, in writing about the Sunda, he did not yet see it as a battleground in the next decade. Yet in geopolitical theory and anticolonial politics, the "Sunda Sea" is key to the very logic of the "Indo-Pacific" at the naissance of the concept.

\section{The "Indo-Pacific" as a counterspace}

Haushofer's "Indo-Pacific" is an integral space, but also a mixed space and a counterspace, a bulwark against the "Atlantic" and "Euro-America." An obvious obstacle to this "Indo-Pacific" vision is that the Pacific Ocean itself is a hybrid space where Anglo-American influence is not only present, but dominant. Haushofer himself admitted that a space such as the "sea coast corridor" along the "Australian oceanic borderline," with both Asian and American geographical features, "is politically torn between the two." ${ }^{\text {"3 }}$ Therefore the mere invocation of the "Pacific" in the "Indo-Pacific" seems to defeat his anti-Anglo-American purpose. Faced with this challenge, Haushofer labored to separate American influence from indigenous Pacific cultures. To this end, he turned to ethnography, especially the historico-anthropological kind practiced by his fellow Ratzel student, Leo Frobenius. ${ }^{34}$ A savvy academic who neither associated with the race theorists nor declined research funding from the Führer and the Duce, Frobenius is known and remembered for his methodology: a procedure called paideuma that traces autochthonous variations, delineates "culture circles," and reconstructs "meaning" out of economic structures. ${ }^{35}$ Although Frobenius's own work focused on Africa, his interlocutor and copresenter Fritz Graebner churned out copious papers on

\footnotetext{
${ }^{32}$ See James D. Hornfischer, Ship of Ghosts (New York, 2009); Walter G. Winslow, The Ghost That Died at Sunda Strait (Annapolis, 1984); Winslow, The Fleet the Gods Forgot (Annapolis, 1994). Yong Yen Nie and Wahyudi Soeriaatmadja, "China's EXIM Bank to Fund Most of Malacca-Indonesia Bridge Project," Jakarta Post, 18 Oct. 2013; Hans David Tampubolon, "US Bank Eyes Sunda Strait Bridge Project," Jakarta Post, 5 July 2012; Satria Sambijantoro, "No More Sunda Strait Bridge Plan," Jakarta Post, 3 Nov. 2014.

${ }^{33}$ Haushofer, Geopolitik des Pazifischen Ozeans, 35.

${ }^{34}$ Haushofer, Geopolitik des Pazifischen Ozeans, Ch. 3 (Eigenwüchsige Wesenszüge im pazifischen Lebensraum), 52: "besonders durch die Forschungen von Frobenius neu zutage Getretene an der Stelle einzureihen, wo wir autochthone Wesensunterschiede der großen Lebensräume der Erde anerkennen müssen, auch wenn wir ihren Platz im Gesamtcharakter und ihre Entstehungsgründe noch nicht genau einsehen."

${ }^{35}$ Leo Frobenius, Paideuma: Umrisse einer Kultur- und Seelenlehre (Munich, 1921); Frobenius, Atlantis: Volksmärchen und Volksdichtungen Afrikas, 12 vols. (Jena, 1921-8); Frobenius, Kulturgeschichte Afrikas: Prolegomena zu einer historischen Gestaltlehre (Zurich, 1933).
} 
"cultural cycles and strata" in Oceania. ${ }^{36}$ The "Frobenius-Graebner methods," Haushofer insisted, are the only way to resurrect "Malayo-Polynesian migrations and their heroic legend" as the pendulum of history first swayed between Paleolithic and Bronze Age cultures. In this way, Haushofer drew from ethnography to show that the "Indo-Pacific" had been highly political since the Paleolithic age, "which the Atlantic never was." 37

Still, Atlantic historians may press further on this question: how did Haushofer reckon with America as an "Atlantic-Pacific" player in "Indo-Pacific" oceanopolitics? To resolve this dilemma, Haushofer designated an Atlantic "American Pacific," and pitted the "Indo-Pacific" against it. In this manner, he both acknowledged America's location near the Pacific, and lumped the United States with the United Kingdom as kindred maritime colonial powers of the West.

Haushofer took several steps to make his case against the "American Pacific." First, he divided the oceanic space of the Americas into multiple spheres: "Euro-America" versus "American Pacific Culture," "Pan-America" versus "American Mediterranean," and so forth. ${ }^{38}$ The weakness of the "American Pacific," Haushofer maintained in his Geopolitics of Pan-Ideas, lies in the tensions between these subspaces. He gloated, cheerfully, "The Pacific position of the US, primus inter pares ... only very laboriously maintains an appearance of equilibrium on the great seas!" Further, he asserted that any idea of a "Pacific America" wouldn't stand the rigorous examination of "pan-thoughts that span the sea." 39 By this rather abstract statement, Haushofer suggested that the Pacific orientation of the US is not theoretically coherent, given the diversity of indigenous ideas across the geo-oceanic space. In other words, the natural seascape of an "American Pacific" would not align with the endogenous cultural forms, social thought, and political consciousness in the region.

In another effort to disintegrate and delegitimate the concept of the "American Pacific," Haushofer argued that its incoherence is not only spatial but also temporal. He emphatically distinguished the modern Anglo-American colonial realm from the indigenous "early American cultural realms." ${ }^{40}$ In other words, the native American cultures are "Indo-Pacific," whereas the colonizing power that became the United States is "Atlantic." Again, the thrust of the argument is to undermine the exogenous "Euro-America" in favour of the authentic "Indo-Pacific." By spatially and temporally breaking down the idea of America as a Pacific power,

\footnotetext{
${ }^{36}$ Fritz Graebner, Methode der Ethnologie (Heidelberg, 1911); Graebner, "Kulturkreise und Kulturgeschichten in Ozeanien," Zeitschrift für Ethnologie 37 (1905), 28-53; Graebner, Das Weltbild der Primitiven (Munich, 1924).

${ }^{37}$ Haushofer, Geopolitik des Pazifischen Ozeans, 51-2: "Es ist mehr als wahrscheinlich, daß er verbreitendes Mittel war bei der ersten Pendelbewegung der kultur zwischen paläolithischer und Bronze-kultur, was vielleicht noch einmal aus der Mythenbildung nachgewiesen werden kann, sowie aus der noch zu entschleiernden Frühgeschichte der malaio-polynesischen Wanderungen und ihrer Heldensage. Für diese Vorgänge ist der Pazifik ein zentrales Becken gewesen, wie der atlantische ozean es niemals war, wobei sich das weite indo-pacifische Ausbreitungsgebiet so vieler verwandter Einflüsse zwischen Howa-madagassischer und amerikano-pazifischer Kultur kartographisch erfassen läßt."

${ }^{38}$ Ibid., $51-2,117-18,127$.

${ }^{39}$ Haushofer, Geopolitik der Pan-Ideen, 40.

${ }^{40}$ Haushofer, Geopolitik des Pazifischen Ozeans, 51. By "Kulturreiche," Haushofer could also be literally referring to the indigenous kingdoms and empires.
} 
Haushofer excluded the United States from "Indo-Pacific" membership. Instead, America belongs to the Atlantic oceanic space, where Germany remained excluded from Anglo-American, Iberian, and French maritime domination.

Overall, as Haushofer legitimized the "Indo-Pacific" as an integral space, he wrestled at length with the heterogeneity of the Pacific Ocean. This heterogeneity is not only endogenous-given the diversity of indigenous cultural forms across Pacific islands-but also exogenous, given European colonizations of the Americas. In the special case of American domination in the Philippines, Haushofer grappled with a transatlantic colonial state on course to become a transpacific coloniser. In response, Haushofer leveraged an ocean of evidence, especially historical ethnography, to cast the United States as an outsider and other to the "Indo-Pacific." Underlying this dazzling array of sources and methods was a concern for the alignment and misalignment of natural, cultural, and political spaces. Haushofer eulogized the endogenous diversity of indigenous "Indo-Pacific" cultures, norms, and institutions, but excoriated "non-Indo-Pacific" colonial dominations. This pattern of thinking was central to Haushofer's political oceanography. To fully grasp it, there is no better way than to appreciate the fluid contexts in which Haushofer put forth the "Indo-Pacific" vision. Next, I will outline Haushofer's political and intellectual contexts. In particular, I show how his intervention in Prussian political thought ended up calling for an "Indo-Pacific" vision involving India and China.

\section{The genesis of the "Indo-Pacific" theory in global contexts The fluid contexts of Haushofer's maritime spatial thought}

Haushofer identified the predicament of Weimar Germany as the same question of geography that had troubled German thinkers since the Prussian era. Although he quickly turned to the Indian and Pacific Oceans to formulate his own answer, Haushofer started with the Prussian tradition. At the very first invocation of the term "Indo-Pacific" in his 1924 treatise, Haushofer at length evoked historical memories of thinkers and practitioners in the Prussian Enlightenment who entertained high hopes for Prussia's global engagement. Haushofer boasted that the "Anglo-Saxons" who "awakened the slumbering gigantic space" were no inferiors to the Iberian and Romance peoples. He singled out the very few German figures who "saw it as a possible task for humanity and even for their own people" to venture into the Indian and Pacific oceans: the naturalist and revolutionary Georg Forster, who, like Haushofer, both theorized the steppe and navigated the sea; Alexander von Humboldt, whom the globe-trotting Haushofer dubbed "the traveller"; and interestingly, the refugee trader Johann Cesar VI. Godeffroy, "the first practical entrepreneur" whose family symbolically fled the land of the philosophes and religious persecutions in 1737 to start a commercial empire in the port city of Hamburg. ${ }^{41}$ At its height, the fleets of J. C. Godeffroy \& Sohn sailed across what

\footnotetext{
${ }^{41}$ Ibid., 10, added emphasis: "Die Angelsachsen haben den schlummernden Riesenraum aufgeweckt, was weder Iberer, noch andere Romanen vermocht hatten, und worin in Deutschland nur ganz wenige Männer eine überhaupt mögliche Aufgabe der Menschheit und gar ihres eigenen Volkes sahen, wie Forster, Humboldt als Weltfahrer und das Hamburger Haus Godeffroy als erste praktische Unternehmer."
} 
Haushofer would call the "Indo-Pacific," between the South African coasts and the islands of Samoa, Fiji, and Tahiti. ${ }^{42}$ Curiously, all three recipients of Haushofer's effusive eulogies-Humboldt, Godeffroy, and Forster-shared deep connections with Anglo-French traditions. Amongst them, Forster outright rejected Prussian politics. But they serve Haushofer's purpose for this precise reason. The point is that the worthy heirs of the ideal of global commerce, either martyred in revolutionary frenzies or forced to flee tyrannies at "the end of Enlightenment," founded another tradition. Translated into German and transplanted in Germany, this tradition was carried on by such intellectual giants as Humboldt, a symbolic link between the Enlightenment and Romanticism. Moreover, all three men were knit through one knot: their intellectual or monetary interests in the Indian or Pacific Oceans.

But Haushofer's German thesis quickly called for “international aid." After all, it is no easy task to deflate the horizon-breaking maritime achievements of the "Romance" peoples in expanding the oceanic frontiers. Struggling to discredit the dominium maris tradition of non-Germanic Europe ever since the Phoenicians, Haushofer was neither able to enlist any mythic proto-Germanic maritime figures, nor willing to redeploy the trope of pseudo-Frankish-Germanic Troy versus proto-Greco-Latin Achaeans. ${ }^{43}$ Instead, he reached out to orientalism to fill in where antiquarianism proved inadequate. To the maritime activity of the Mediterranean peoples from the Phoenicians to the Romans, and subsequently "Iberian and French contributions," he stingily and sardonically ascribed the label "more littoral and thalassic than oceanic." Here, the standard of comparison is not the maritime accomplishment of the Germans, but that of the Arabs and the Chinese, who used to come across each other, from time to time, "in their Indo-oceanic area." ${ }^{\prime 4}$ What to make of Haushofer's seeming assignment of the "Indo-oceanic realm" to Chinese proprietorship in Sino-Arab maritime encounters? And what historical episodes was he referring to? Setting aside the steppe-style clash of the Abbasid Caliphate and the Tang Empire, Haushofer jumped straight to the height of Sino-Arab maritime trade in the Song-Ming Dynasties. In particular, he possibly alluded to the epic expeditions of Zheng He's treasure fleet from Southeast Asia to Arabia, across the entire (later) non-Anglo-American portion of the "Indo-Pacific." 45 It remains unclear whether by "their Indo-Pacific"

\footnotetext{
${ }^{42}$ Richard Hertz, Das Hamburger Seehandelshaus J.C. Godeffroy und Sohn, 1766-1879 (Hamburg, 1922); Kurt Schmack, J. C. Godeffroy \& Sohn Kaufleute zu Hamburg (Hamburg, 1938); Helmut Washausen, Hamburg und die Kolonialpolitik des Deutschen Reiches (Hamburg, 1968); Gabriele Hoffmann, Das Haus an der Elbchaussee (Hamburg, 1998).

${ }^{43}$ For how Francio, the other son of Priam, might just have settled on the Rhine, see George Huppert, "The Trojan Franks and Their Critics," Studies in the Renaissance 12 (1965), 227-41.

${ }^{44}$ Haushofer, Geopolitik der Pan-Ideen, 54: "mehr litoral und thalassisch als ozeanisch steuern die Phoeniker, Hellenen, Römer und Romanen, diese in iberischer, dann französischer Fortwirkung bei; Araber bauen (von Chinesen $\mathrm{ab}$ und $\mathrm{zu}$ in ihrem indo-zeanischen Bereich durchfahren) die von Admiral Ballard in 'The rulers of the Indian Ocean' beschriebene Ideologie des Indischen Ozeans aus, ehe sich die Iberer, Niederländer, Franzosen, Briten ihrer der Reihe." The syntax is puzzling. In all likelihood, the possessive determiner here refers to the Chinese, or both the Arabs and the Chinese. I thank Steven Grundy and Amelia Bonea for our discussions on the grammar of the text.

${ }^{45}$ Narratives on the exploits of the treasure fleets are not absent in Western print culture; see e.g. Juan González de Mendoza's Historia de las cosas más notables, ritos y costumbres del gran reyno de la China
} 
Haushofer implied maritime custodianship, if not sovereignty. At any rate, Chinese navigators neither saw the sea they traversed as "theirs" nor invented ideas comparable to a claim of maritime jurisdiction. ${ }^{46}$ But to Haushofer, one historical anecdote of Sino-Arabian "Indo-Pacific" custodianship sufficed to dwarf the historical foundation of Euro-American maritime domination. With "smallness thrust upon them" by Haushofer, maritime rivals of Germany were deprived of historical legitimacy, hence contemporary agency, in the reconstructed "Indo-Pacific" space.

A synopsis of Haushofer's numerous pan-ideas in the 1920s-1930s shows that he repeatedly turned to South, East, and Southeast Asia to extricate Germany from its geopolitical predicament. In fact, he performed more than one historical thought experiment on the global space to connect the Chinese and Indian spheres. Between his 1924 and the 1939 treatises, Haushofer also conceived an "Indo-Serian" vision in his Geopolitics of Pan-Ideas (1931), to revive the "old Silk Road through the Yumen passage." ${ }^{47}$ The land-based northern Seres, in contrast to the maritime southern Sinae, is a term occasionally invoked in early modern natural jurisprudence. In Mare Liberum Grotius refers to Seres, along with Arabia and India, based on Roman geographer Pomponius Mela. ${ }^{48}$ The "Indo-Serian," however, is found uniquely in Haushofer. With this odd coinage and its ethnographical reference to the silk-trading Serici, the pedantic Haushofer shows his resolve to incorporate the Indic and Sinic spheres on land and on sea. ${ }^{49}$ Faced with a chaotic Inner Asia plagued by Russo-British competition, and a South Asian pathway to Tibet under British domination, Haushofer was hardly in a position to elaborate on how to re-create the "Indo-Serian" Silk Road. And as he prioritized the maritime "Indo-Pacific" over the terrestrial "Indo-Serian," Haushofer's spatial political thought turned oceanographic.

(Rome, 1585), translated into English by Robert Parke: The History of the Great and Mighty Kingdom of China and the Situation Thereof, ed. Sir George Thomas Staunton, 2 vols. (London, 1853; first published 1588); into German by Johann Kellner: Ein Neuwe/Kurtze/doch warhafftige Beschreibung deß gar Großmächtigen weitbegriffenen/ bißhero vnbekandten Königreichs China ... (Franckfurt am Main, 1589); and Matthaeus Dresser and Thomas Harriot: Historien und Bericht, Von dem Newlicher Zeit erfundenen Königreich China ... (Leipzig: Schnelboltz, 1597), as well as into French, Italian, Dutch, and Latin.

${ }^{46} \mathrm{Ma}$ Huan (馬歡), Ying Ya Sheng Lan (汶涯勝覽) (1451) (Jinan, 1997; Taipei, 2005), esp. on Yavadvipa in Indonesia. Ma draws upon earlier sources such as Wang Dayuan (汪大洣)'s Yi Dao Zhi Lue (島夷誌略). Wang the merchant traversed South and Southeast Asia, and allegedly reached North and East Africa.

${ }^{47}$ Haushofer, Geopolitik der Pan-Ideen, 32: "aber auch die der alten Seidenstraße durch die Yumon-Passage. Es ist bezeichnend, wie die Lieblingswege der indo-serischen Kultur.”

${ }^{48}$ Hugo Grotius, Mare Liberum (Leiden, 1609; Leiden, 2009; Indianapolis, 2004) Cap. 5: "solamque Indiam quingenties sestertium, si Arabiam addas et Seres," Cap. 8, "quo fere modo apud Seres dicitur rebus in solitudine relictis sola mutantium religione peragi commercium."

${ }^{49}$ The "Serischen" in "Indo-serischen," adjective of Die Serer (Silk Road: Seidenstraße), comes from Seres

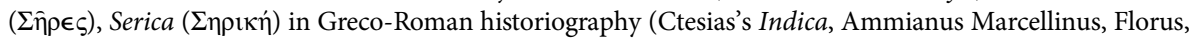
Pausanius). Later writers on silkworms and the Silk Road, such as Henry Barham (1670?-1726), who traced silk expertise to Noah, take it for China (Henry Barham, An Essay upon the Silk-Worm (London, 1719), Ch. 1, "Of the Antiquity of Silk," 16), whereas others prefer Khotan or Kashmir, since the "Serians" roamed between Buchara, Kotschotei and the Tarim Basin. See Pliny the Elder, Naturalis Historia, 6.17/20/24; Ptolemy, Geographia, 7.5; Lucan, Pharsalia, B. x. 141; Pliny, 34.4141; Pomponius Mela, De Situ Orbis, 3.7; Strabo, Geographia, 11.11.1, 15.1.34, 15.1.37. At least the distinction between the terrestrial Seres and the maritime Sinae (e.g. later Cathay and Mangi) is clear. 
In this way, Haushofer's pledge to pave a new path for Germany called for a global vision. In view of his pivot to Asian sources against Euro-American influences, Haushofer's Weimar context was intertwined with the interwar politics of South and East Asia. In fact, Haushofer's international intellectual contexts were long in the making. To better understand the Sino-Indian foundation of his anticolonial "Indo-Pacific," it is important to examine the contexts of oriental studies and orientalism, especially Haushofer's reception of European scholarship on India and China.

\section{Haushofer's Eastern contexts: the politics of indology and sinology}

Haushofer assigned China and India key roles in the "Indo-Pacific" vision. He was keenly interested in both the cultural traditions and republican movements in India and China, thanks to both his German academic circles and interpersonal connections across Eurasia. It is tempting to ignore the vital places of India and China, given the singular place of Japan in Haushofer's writings. After all, he devoted numerous publications between 1913 and 1941 to the study of Japan. But the weight of Japan in Haushofer's oeuvre; the enthusiastic reception of Haushofer in Japanese social, political, and academic circles; and the historical fact of the Tripartite Pact should not overshadow India and China as two stimulating case studies that fuelled Haushofer's spatial imaginations in the interwar period. ${ }^{50}$ In fact, Haushofer considered the "Indo-Pacific" case of Japan as an island-state to be simpler than what he called the "hermaphrodite and transitional spaces" (Zwitter- und übergangsräume)-that is, between terrestrial and maritime forms of political life-of the "Inner Crescent." By "Inner Crescent," Haushofer received but diverged from the Anglo-American school of "crescent theories." From Halford Mackinder's Inner versus Outer Crescent and Georg Simmel's "spatial sociology" to Nicholas J. Spykman's conceptualization of the "Rimland," these theorists all ask, albeit in different ways, how great powers clash over resource-rich spaces in between. ${ }^{51}$ Haushofer, by contrast, raised the question of "sovereign space" from the point of view of the locals. Indeed, the more interesting question is how modern bounds of statehood could-or indeed couldn't-match to the complex geo-oceanographic features formed through long historical processes of the world. In other words, how to balance the "state idea" and the "land concept"? ${ }^{52}$

Haushofer believed that the way China eventually resolves this question would apply equally to Central Europe, the Near East, and the Middle East. Along with his Indian liaison Benoy Kumar Sarkar (1887-1949), Haushofer speculated that the unfolding of the Chinese republican revolution of 1911, which by 1924 had descended into a chaotic power struggle, pointed to the future solution of the Indian

\footnotetext{
${ }^{50}$ In fact, Haushofer's ties with Japan are counterproductively overworked. See Spang's critique of Herwig's narrative on Haushofer's "Pro-Japanese activities" in Spang, "Revisiting Karl Haushofer at 150, , 29-30.

${ }^{51}$ Brian Blouet, "The Political Career of Sir Halford Mackinder," Political Geography Quarterly 6/4 (1987), 355-67, at 191-2; Murphy, "Hitler's Geostrategist?", 4; Nicholas J. Spykman, The Geography of the Peace (New York, 1944); Spykman, The Social Theory of Georg Simmel (Chicago, 1925).

${ }^{52}$ Haushofer, Geopolitik des Pazifischen Ozeans, 171-2.
} 
imperial question. ${ }^{53}$ In fact, Haushofer's own ties to key anticolonial activists in Berlin, notably Virendranath Chattopadhyaya and Agnes Smedley, proved also ties to Chinese activism. ${ }^{54}$ This falls neatly in line with prevalent interwar narratives about the tightly bound fates of Indian and Chinese republicanisms, as revealed in recent works on the League against Imperialism. ${ }^{55}$ whilst international eyes were on the colourful election briberies and the simmering coup d'état (1923-4) in the old imperial capital, Haushofer averred that the motive power for paradigm changes resided in two figures only: Zhang Zuolin of Manchuria the "CondottieriGeneralgouverneur" and Sun Yat-sen of Sikiang, "the prototype of AnglicizedReformed Chinese." Above all the dramas in the Central Plains, what captured Haushofer's imaginations were the two coastal maritime habitats by which the two camps were identified: access to the West Pacific via Bohai and Huanghai, and the waterways from the Pearl river delta to the South Seas, the Indian Ocean, and the southwestern Pacific. His prediction of China's political future would turn out to be surprisingly apt in six years' time, when the second generation leaders of these two blocs for the first time unified Republican China, in name if not in effect. Haushofer's acumen, however, was barely received in China. Other than a translation of the Defence Geopolitics: Geographic Basis of Military Science (Wehr-Geopolitik: Geographische Grundlagen einer Wehrkunde, 1932) by Zhou Guangda in 1945, Chinese reception of Haushofer remains scant to the present day. ${ }^{56}$

Haushofer's situation of China and India at the heart of the "Indo-Pacific" vision was a product of his time and of his own intellectual encounters. At the time, German ethnography was a mediating ground for geo-oceanographers and comparative philologists. Haushofer humbly deferred all matters Sinic, ancient and modern, to the authority of Sanskritist-turned-sinologist Otto Francke (18631946), whom Hellmut Wilhelm dubbed the "Nestor of German sinology." Haushofer compared Francke's "New Formations of East Asia" (1911) and "Great Powers in East Asia" (1923) to Sarkar's "Futurism of Young Asia" (191718), as two sources on "Indo-Pacific" consciousness. ${ }^{58}$ Thus informed, Haushofer

\footnotetext{
${ }^{53}$ For a stimulating study of Haushofer and Sarkar see Luna Sabastian, "Spaces on the Temporal Move: Weimar Geopolitik and the vision of an Indian Science of the State, 1924-1945," Global Intellectual History 3/2 (2018), 231-53.

${ }^{54}$ Chatto (1880-1937) was closely associated with Liao Huanxing (廖焕星, 1895-1964). Other Chinese representatives included Liu Puqing (柳溥慶, 1900-1974), and Shao Lizi (邵力子, 1882-1967). Soong Ching-ling (宋慶齡, 1893-1981) also pledged support. It is well known that Smedley (史沫特萊) later connected with Chinese communists.

${ }^{55}$ Michele Luoro, Comrades against Imperialism (Cambridge, 2018); Michele Luoro, Carolien Stolte, Heather Streets-Salter, and Sana Tannoury-Karam, eds., The League against Imperialism (Chicago, 2020).

${ }^{56}$ Karl Haushofer (豪士浩華), Guofang Dilixue (國防地理學), trans. Guangda Zhou (周光達) (Chongqing, 1945). See also Marc Andre Matten, Imagining a Postnational World: Hegemony and Space in Modern China (Leiden, 2016), 23 n. 36. In China, most of Mackinder was known after 1949. But Zhou's work established the translation of Geopolitik as 地緣政治, a term still in use today. For 地緣, see Guanzi (管子): “故緣地之利, 承從天之指, 辱舉其死, 開其國門, 辱知其神; 緣地之利者, 所以參 天地之吉綱也.”

${ }^{57}$ Hellmut Wilhelm, “German Sinology Today," Far Eastern Quarterly 8/3 (1949), 319-22.

${ }^{58}$ Haushofer, Geopolitik des Pazifischen Ozeans, 172; Otto Francke, Ostasiatische Neubildungen (Hamburg, 1911); Francke, Die grossmächte in Ostasien von 1894 bis 1914 (Braunschweig, 1923). Benoy
} 
counted on young, and preferably German-trained, Chinese and Indians to unleash a new wave of national self-determination throughout South and East Asia, in order to offset the "Euro-American" colonial clout. ${ }^{59}$

An important dimension of Haushofer's interest in the East is what may be called the politics of oriental studies. In 1923, when Haushofer was finalizing his tract, his main source on China, Otto Francke, assumed the chair of sinology at the University of Berlin vacated by the Dutch scholar J. J. M. de Groot. The coronation marked the persistent preeminence of German sinology in Berlin, despite the German loss of the Jiaozhou Bay (Kiautschou Deutsches Schutzgebiet) in Paris. As his citations show, Haushofer took seriously the opinion of Admiral Ballard (18621948) that Maximilian von Spee's undeserved defeat at the hands of the Japanese (supported by the British) was symptomatic of the delicate balance of maritime power in the East China Sea. ${ }^{60}$ The nexus of Haushofer's interests in German sinology and Germany's position in China is hardly surprising, for oriental studies and colonial politics were always intertwined. ${ }^{61}$ And Haushofer rightly appreciated Francke's legacy in the history of German and world sinology. ${ }^{62}$ In a way, scholarship in sinology, indology, and historical philology is a token of national influence alternative to colonial power-where, by 1924, Germany had fallen far behind.

The politics of oriental studies also applies to indology, another interest of Haushofer.$^{63}$ Indology in the second half of the nineteenth century was rife with quarrels between English and German gurus. The most dramatic episode of politicized Sanskritology was the public bid for the Boden Professorship at Oxford by Max Müller and Monier Williams. On 7 December 1860, amidst marches and manifestoes, nonresident dons and faraway masters, alumni rode on special trains back to Oxford to indulge the proper Englishman with a majority of 220 votes over his

Kumar Sarkar, "Futurism of Young Asia," International Journal of Ethics 28/4 (1918), 521-41. The text was delivered as a lecture in 1917 at the then excellent Clark University.

${ }^{59}$ For another of Haushofer's calls for the oneness (Einheit) and self-determination (Selbstbestimmung) across the Indo-Pacific, and for its peoples to "regain consciousness," see Haushofer, "Die Einheit der Monsunländer," 107, 117.

${ }^{60}$ George Ballard, Rulers of the Indian Ocean (London, 1927), 314: "but a detached squadron of American cruisers based on the Philippines-of the composition of the German force stationed at Tsingtao under Von Spee in July 1914-would be a very grave danger to the British situation in the East, unless masked by at least an equal force based on Singapore. Von Spee was compelled to retreat across the Pacific because the whole Japanese navy joined in the hunt against him."

${ }^{61}$ Haushofer's ties to German operations in China did not end with the siege of Tsingtao. One of Haushofer's likely students in the Bavarian War Academy (Bayerische Kriegsakademie), Hermann Kriebel (1876-1941) pursued a career in China as a miltiary adviser and consul.

${ }^{62}$ As it turned out, the next generation of international sinologists would be first groomed in Francke's German school: George Kennedy of Yale, Étienne Balazs of the École des hautes études, and Wolfram Eberhard of Berkeley. However, Haushofer would later observe an exodus of German sinologists (and to some extent indologists) in the late 1930s and 1940s. See Martin Kern, "The Emigration of German Sinologists 1933-1945" Journal of the American Oriental Society 118/4 (1998), 507-29.

${ }^{63}$ For Haushofer, figures such as Franz Bopp connect the dots. Bopp, coming from the Mainz moment of the Prussian Enlightenment, inherits and represents the old generation of Franco-Prussian Sanskritists: Jean François Pons, Antoine-Léonard de Chézy, Silvestre de Sacy, Louis Mathieu Langlès. By Haushofer's time, German indology had become the centre. 
"Continental" and "philosophical" German rival. ${ }^{64}$ In the wake of the Indian Rebellion of 1857, the Oxford electorate grew profoundly suspicious of Sanskrit studies that did not contribute to colonial governance or missionary work, such as Müller's Vedic scholarship, despite the man's greater command of historical philology. This election has been remembered by many as an example of anachronism and academic prejudice in the Oxford system, if not a symptom of "English injustice" per se. Haushofer was conversant with Müller's legacy in the academic context. Although Sanskrit was never his forte, Haushofer followed Müller's linguistic theorizations of Indo-European, partly based on Vedic evidence, an illustrious line of research which Walther Wüst would infamously spin to the liking of Dietrich Eckart. Although Haushofer refrained from wading into the deep waters of India studies, he enlisted collaborators. In 1928 he cofounded the India Institute of the Deutsche Akademie with the anti-British Bengali intellectual Tarak Nath Das (1884-1958), who brought from the Kansas Leavenworth prison to Munich, first, grave grievances in the 1917 "Hindu-German Conspiracy Trial"; second, a book recently completed in California entitled Is Japan a Menace to Asia? prefaced by the Chinese politician Tang Shaoyi, with an appendix by Tokutomi Lichirō, the editor-in-chief of Kokumin Shimbun (國民新聞); and third, an ambitious plan to bring Indian students en masse to receive German education. ${ }^{65}$ The institute they cofounded to foster Indo-German connection would be renamed "Max Müller Bhavan." ${ }^{66}$ Indeed, the program recruited students from the Arya Samaj (आर्य समाज), an organization which propagated the theory of indigenous Hindu Aryans, allegedly grounded in the Vedic tradition. In this wise, the Vedas became symbolically linked to Indo-German cultural exchange as an oceanopolitical strategy.

Together, the contexts of India and China formed the intellectual seascape of the "Indo-Pacific." Strategically, the political resurrection of South and East Asia, even if not as German allies, would undercut the colonial clout of Western Europe and the United States.

\section{Political resurrection of the "Indo-Pacific"}

\section{The "Indo-Pacific" as an anticolonial coalition}

Haushofer diagnosed the current state of the "Indo-Pacific" toward the goal of its political resurrection. First, to confront the "Euro-American" challenge, the

\footnotetext{
64“"Editorial," The Times, 29 Oct. 1860, 6; "University Intelligence," The Times, 15 May 1860, 9, 16 May 1860, 9, 23 May 1860, 9, 28 May 1860, 6, 27 June 1860, 12, 17 Aug. 1860, 7, 22 Oct. 1860, 7, 22 Nov. 1860, 10, 8 Dec. 1860, 9; Max Müller, MA (All Souls' College, Oxford, 30 Oct. 1860), "The Sanskrit Professorship" (letter to the editor), The Times, 31 Oct. 1860, 10. "Boden Sanscrit Professorship," The Observer, 3 June 1860, 3.

${ }^{65}$ The booklet was published in Shanghai in 1917, copy consulted at Cornell University Library. Tang Shaoyi (唐紹儀, 1862-1938) served as premier of the Republic of China; Tokutomi Lichirō (德富猪一郎, 1863-1957), sometimes misspelled Ichiro Tokutomi (德富一郎) by anglophone archivists who omit the syllable for “swine," is the original name of the right-wing Japanese thinker Tokutomi Sohō (徳富蘇峰).

${ }^{66}$ Benjamin Zachariah, "Transfers, Formations, Transformations? Some Programmatic Notes on Fascism in India, c.1922-1938," in Jörg Feuchter, Friedhelm Hoffmann, and Bee Yun, eds., Cultural Transfers in Dispute (Frankfurt, 2011), 167-92, at 190.
} 
"Indo-Pacific" must overcome its demographic constraint. On his way to explore the political potential of the "Indo-Pacific," Haushofer deployed his spatial theory to attack a "sixty-four-thousand-dollar question" in modern politico-economic thought: why did industrialization break out in the Atlantic but falter in Asia? Haushofer's idiosyncratic answer lies in the spatial structure of the "Indo-Pacific" at large. According to this theory, the expansive traffic space (Verkehrsraum) and the confined settlement spaces (Siedlungsräume) are decidedly out of proportion, due to the geographic diversity of the "Indo-Pacific." That is why, despite their seemingly large extent, "Indo-Pacific" countries have been serially strained by population growth. But since that pressure always gradually dissipated by customary self-control, it had never boiled over to the point of propelling an industrial breakthrough. Haushofer's prescription, then, was to devise demographic policies that strike "a bearable balance between popular pressure and tight space." Needless to say, Haushofer's spatio-demographic theory was logically different from other population theories in the Third Reich, e.g. Walter Christaller's theories of "empty space" (Freiraum) rolled out in 1940-1. ${ }^{68}$ Moreover, Haushofer's approach to political demography applied to vast spaces across land and sea. By his own account, it concerned not only economic activity but also an "artistic stimulus" that explains the incredibly complex sociological forms in Central Europe, Italy, India, Japan, and China's east coasts and central plains. ${ }^{69}$ In this larger global vision, two sets of spaces-the densely populated Central Europe and Mediterranean, and the overly crowded Indian, Chinese, and Japanese communities-together form a counterpart to the Atlantic world, or "Euro-America." And here, too, Haushofer takes care to invoke Sarkar's approval of the "Indo-Pacific" versus "Euro-America" paradigm. ${ }^{70}$

As a champion of the "Indo-Pacific" cause, Haushofer watched the Euro-American pivot to Asia on high alert. In particular, he was alarmed that the "American Mediterranean," which he deemed deeply Atlantic-European in nature and organization, might be replicated in the "Australasian Mediterranean." ${ }^{\text {" }}$ Begrudgingly, he rambled on about the expanding American spheres of influence: the United States had extended the "Pacific thresholds" to a larger "American Mediterranean" encompassing Panama, Cuba, Puerto Rico, San Domingo, the Virgin Islands, and Haiti-together 282,000 square miles with almost 20 million inhabitants-greatly outnumbering the 245,000 square kilometers and about 400,000 inhabitants of the German South Sea empire. ${ }^{72}$ This jealousy of

\footnotetext{
${ }^{67}$ Haushofer, Geopolitik des Pazifischen Ozeans, 102.

${ }^{68}$ Walter Christaller, Die zentrale Grundgedanken zum Siedlungs- und Verwaltungsaufbau im Osten, Neues Bauerntum 32 (1940), 305-12; Christaller, Raumtheorie und Raumordnung, Archiv für Wirtschaftsplanung 1 (1941), 116-35; Christaller, Die zentralen Orte in den Ostgebieten und ihre Kulturund Marktbereiche, vol. 1, Von Struktur und Gestaltung der zentralen Orte des Deutschen Ostens (Leipzig, 1941).

${ }^{69}$ Haushofer, Geopolitik des Pazifischen Ozeans, Ch. 7 ("Pazifische Soziologie"), 102.

${ }^{70}$ Ibid., Ch. 8 ("Der Einbruch der weissen Rasse"), 117-18.

${ }^{71}$ Ibid. By the "American Mediterranean" Haushofer meant the body of water across the Gulf of Mexico and the Caribbean Sea, draine by North American, South American and Meso-American rivers (e.g. the Magdalena, Mississippi, Belize, Rio Colorado, etc.) and its outskirts. This loose term, now obsolete by oceanographic standards, remains a vague and informal reference.

${ }^{72}$ Ibid.
} 
the size of habitats and inhabitants shows that Haushofer was conscious of a German-versus-American race to make and remake the "Indo-Pacific." His strategy was to countervail the "Euro-American Mediterranean" by integrating the space stretching from the Monsoon Subcontinent to Macau and Malacca. The historic opportunity in German outreach to India and China was the creation of this maritime "Indo-Pacific" belt as an anti-American project.

Haushofer realized that, for the purpose of internal "Indo-Pacific" unity against Euro-American encroachment, it was crucial to forestall any attempt to pit the "more Indian" against the "more Pacific" spaces within the maritime belt. This is a serious challenge, and a thorny issue in public debates over the selfdetermination of Southeast Asia, the melting pot of Sinic and Hindu influences since antiquity. Against the popular opinion that these two elements are so different that even European colonialists resorted to different approaches of governance, Haushofer replied that the best "cultural politicians" must adopt a unified approach to govern any "Indo-Pacific" life space with success. Elsewhere sensitive to "Indo-Pacific" heterogeneity, Haushofer here warned against taking too many cultural-geographical peculiarities into account. Allegedly, it was due to the exaggeration of local cultural differences that colonial governors tended to adopt harsher measures than those policies emanating directly from the home country. ${ }^{73}$ Doubling down on this point, Haushofer laid into the overuse of cultural geography to demarcate maritime political spaces. Historical contingencies such as the Hindu-Sinic cultural divide in Southeast Asia disturb the calm objectivity of geophysical features: the life cycles of marine species, the procession of oceanic currents, and the direction of sea winds. Here, Haushofer returned to oceanography in his rhetoric, not without reason. Neither a sinologist nor an indologist by training, Haushofer struggled to invent a culturalgeographic theory that would fuse the Sino-Hindu spheres of the "Indo-Pacific." Therefore he resorted to reorganizing political spaces according to the reconceptualization of natural spaces.

Ultimately, Haushofer failed to establish a groundbreaking approach to rethink the relationship between Indian and Chinese traditions in Southeast Asia. But the problem he identified endures to the present day. Twenty-first-century "Indo-Pacific" strategists struggle to answer the same question on the physical unity and cultural disunity of the region, especially in Southeast Asia. So far, "Indo-Pacific" advocates have relied on the perceived similarity in the political institutions of Japan, India, and the United States to lay a common ground for unity. However, this "unity" fails to account for major differences in the forms of culture, society, and governance in the vast spaces between a handful of Washington's avowed allies. In contrast, Haushofer's sense of unity runs deeper than political institutions, to the level of political cultures. There, the answer is not as facile. Regardless of his motives, Haushofer's "Indo-Pacific" took the question of indigenous and colonial politics seriously. And in search of the right way to harmonize Indian and Chinese influences, Haushofer had the foresight to identify Southeast Asia as a key space within space. The political resurrection of Southeast Asia was to become a bulwark against Anglo-American expansions into the "Indo-Pacific."

\footnotetext{
${ }^{73}$ Ibid., 106.
} 


\section{Manila and Malacca: the "Indo-Pacific" as a bulwark against Anglo-American influences}

Haushofer argued for "Indo-Pacific" self-determination in two pivotal spaces: Manila and Malacca. In Pacific Ocean, he reserved the harshest words for the American transplantation of the "Atlantean" model of imperialism in the "Indo-Pacific" Philippines. Here, the man today remembered as the "Crown geopolitician" of the Reich blasted "imperialism" through the explicit language of comparative political theory. He mocked the Americans for not recognizing the appeal of a peculiar sense of self-determination amongst the "Indo-Pacificians" whose indigenous thought strikes a greater political balance than the Euro-American tradition. Western intervention in the "Indo-Pacific," the argument goes, is seen unfavourably "through the eyes of Buddha, Gandhi, and Tagore," especially when compared to the standard of Chinese political philosophy. ${ }^{74}$ Convinced that the "Indo-Pacificians" embrace a sensible and unified cultural worldview in the "space of monsoon-land," Haushofer found something to praise even in the "semantic disharmonies" of geographic names across this region-Indochina, Australasia, Malaysia, and "Insulindia." ${ }^{, 75}$ Famous for his own penchant for pan-ideas, Haushofer proposed that the prolific use of compound terms reveals a special "Indo-Pacific" sensitivity to productive tensions in their spatial language. ${ }^{76}$ Returning to his strategic vision, Haushofer exhorted the form-torn and soul-torn "Indo-Pacific" to selfdetermination from Anglo-American-French-Dutch-Portuguese dominations. In context, this endorsement of self-determination was a default position for interwar Germany. So Haushofer's rhetoric fits the larger story. What is distinctive, however, is his argument, one that is based on the politico-oceanographic vision of the "Indo-Pacific."

Haushofer censured not only American Manila but also British Singapore, both urban centres of their respective "Mediterraneans." The two spaces are also the geopolitical manometers of the larger "Indo-Pacific." And these manometers, in turn, are determined by a set of vectors: capital, culture, urbanisation, and marginal growth. Strategically, Haushofer's designation of Malacca as the "the key point in the Indo-Pacific" echoes Admiral Ballard's selection of Singapore as the "proper watching station for ships covering the Indian Ocean." ${ }^{\text {" }} 7$ Historically, it stands well within the four-century-long tradition of Portuguese, Dutch, and English political thought experiments on international justice off the coasts of Macao and Malacca. But besides the strategic and rhetorical contexts, there was a more pressing political context to Haushofer's focus on Malacca. In the 1910s-1920s, Malaysia witnessed the consolidation of seven polities under British imperial paramountcy: the Straits Settlements, the Federated Malay States, Perlis, Kedah, Kelantan, Terengganu, and Johore. A further

\footnotetext{
${ }^{74}$ Ibid., Ch. 16 ("Imperium pacificum und Selbstbestimmung"), 231: "An ihnen erhellt, daß es einen Sondertyp pazifischer Selbstbestimmungsideale gibt, der sich vom atlantischen unterscheidet, und der auch auf die Formen des Imperialismus im Pazifik umgestaltend einwirkt. Es erhellt auch, daß ein stärkerer Ausgleichszug darin herrscht, als in der atlantischen Welt, deren Methoden man im Indo-Pazifik vielfach mit den Augen Buddhas, Gandhis und Tagores ansieht, und unvorteilhaft mit den Maßstäben der chinesischen Staatsphilosophie auswählend vergleicht."

${ }^{75}$ "Insulindia" is an obsolete term that refers to maritime Southeast Asia.

${ }^{76}$ Ibid., Ch. 13, 182.

${ }^{77}$ Ballard, Rulers of the Indian Ocean, 311.
} 
entrenched British presence in this period ended lingering Dutch influence in the region, which had waned steadily throughout the Napoleonic wars, declined precipitously from the Anglo-Dutch Treaty of 1824 to the Pangkor Treaty of 1874, and had almost vanished by the Anglo-Siamese Treaty of $1909 .{ }^{78}$ When Haushofer crafted his first formulation of the "Indo-Pacific," however, the English had not yet fully reorganized or militarized this loose string of territories under the Crown. But anticipating such a move-which would not come about until the end of World War IIHaushofer speculated that "the expansion into a first-rank sea base would not fail as a simultaneously reassuring and admonishing symbol of England's overshadowing in Dutch India, and as a soul-strengthening one in Australia." ${ }^{19}$

In both Manila and Malacca, Haushofer's avowed aim to breathe political life into the "Indo-Pacific Ocean" is clear from the strategic standpoint of interwar Germany. Given the long history of Euro-American involvement in South, Southeast, and East Asia, as well as the entrenchment of British influence in Australasia, it was both too late and too costly for Germany to operate as a colonial imperial power in the region. Therefore Haushofer turned to "Indo-Pacific" political resurrection, not German recolonization or rearmament. But it is not the case that Haushofer evaded the prospect of reestablishing German military superiority over the oceanic space. Haushofer did realize, for instance, that new technologies might alter the balance of power on the ocean at a faster pace and on a larger scale. A decade before Schmitt ruminated on new submarines and aeroplanes in Land and Sea, Haushofer had already theorized the spatio-political effects of U-boats and seaplane tenders on the future of the "Indo-Pacific." ${ }^{80}$ But Haushofer's larger vision was a political one. He hoped that the self-determination of "Indo-Pacific" colonies, rather than another European war, would rebalance the international order.

Haushofer envisioned the future "Indo-Pacific" as a self-conscious political body. Possibly and preferably, the new "Indo-Pacific" would boast German-educated Indian leaders on the front lines of anticolonial resistance, and German-trained Chinese soldiers behind the republic's barricades. ${ }^{81} \mathrm{~A}$ moderate but robust maritime "Indo-Pacific" belt, even if not a formal ally, would amplify if not echo German voices on the continent in better times and come to its aid should fortune turn its tides. But to a Germany unhopeful for recolonization, the self-determination of a decolonized "Indo-Pacific" itself would be a sizeable gain. Indeed, Haushofer took care not to specify any diplomatic alliance with Germany as a prerequisite for the "Indo-Pacific" project. Between the lines, the underlying message was that even

\footnotetext{
${ }^{78}$ Willam R. Roff, The Origins of Malay Nationalism (New Haven, 1967).

${ }^{79}$ Haushofer, Geopolitik des Pazifischen Ozeans, Ch. 23 ("Eigenart der pazifischen Wehrgeographie"), $317-18$.

${ }^{80}$ Ibid: "Natürlich wird es in Zukunft auch das U-Boot und das Flugzeugmutterschiff leisten können ... Sie alle lagern in ihrer kulturmorphologischen Schichtung quer über den Großen Ozean hinweg, verfolgbar von der indischen inselwelt bis in die frühamerikanischen Kulturreiche." Contrast this ethnographical view to Schmitt, Land und Meer.

${ }^{81}$ Bernd Martin, ed., Die Deutsche Beraterschaft in China 1927-1938 (Düsseldorf, 1981). Prominent German miltiary advisers to China include Max Hermann Bauer (1869-1929), invited by Zhu Jiahua (Chu Chia-hua, 朱家驊) to serve the Nanjing government six years after the Kapp Putsch (1920). The Bayerische Kriegsakademie alumnus and 1923 Munich Putsch veteran Hermann Kriebel is an acquantaince and possible student of Hauhsofer.
} 
without German leadership, the "Indo-Pacific" region should and would cast down the shackles of colonial domination to regain its overdue political consciousness.

A restrained and realistic prescriber of oceano-political medicines, Haushofer was aware that he offered political theory, not diplomatic practice. ${ }^{82}$ At a distance from Germany's negotiating tables and foreign-policy meetings, Haushofer entertained global spatial imaginations that were, admittedly, difficult to translate into diplomatic measures. But precisely for this reason, the "Indo-Pacific" vision assumed a global oceanic shape that extended beyond interwar German diplomacy, even though Haushofer's concerns, motivations, and sources were deeply rooted in their contexts. Indeed, the original "Indo-Pacific" concept, in its historical specificity, provokes us to interrogate the alignment and misalignment of the natural environment and political consciousness, the tensions between indigenous culture and colonial governance, as well as the possibility and limitations of reconceptualizing terrestrial and oceanic spaces to rethink international politics. Interestingly and ironically, Haushofer's concern for interwar Germany in international power struggles morphed into a spatial discourse on anticolonial world making. Once we begin to reflect on what the "Indo-Pacific" was as an anticolonial vision, we are able to turn the return of the "Indo-Pacific" into an opportunity to rethink how space could be reconceptualized for anticolonial political thought. More broadly, just as the recovery of a contextualized political concept induces us to rethink political languages of our own time, a critical restoration of Haushofer's "Indo-Pacific" idea challenges us to wrestle with the same questions Haushofer raised, answered, or failed to resolve.

\section{Conclusion}

Karl Haushofer's "Indo-Pacific" is a historically grounded and theoretically innovative politico-oceanographic vision. In this first study of Haushofer's "Indo-Pacific" concept in political thought and intellectual history, I have attempted to unravel the inner logic, discursive structure, and political implications of what the "Indo-Pacific" really was. The underlying political oceanography, for all its flaws, makes a serious contribution to the conceptualization of maritime global space. ${ }^{83}$ It is a great loss to miss the thick layers of Haushofer's "Indo-Pacific" concept: its case for rethinking the conventions of demarcating global spaces, its regard for indigenous political lives in oceanic spaces, and its call for anticolonial politics to remake the international order. This is so, not least because all such questions are missing in the contemporary discourse on the "Indo-Pacific" as a site for great-power diplomacy. Regrettably, whereas historians have yet to explain

\footnotetext{
${ }^{82}$ Spang notes Haushofer's repeated exposition of the " 25 percent idea" that geopolitics explains only 25 percent of politics. Spang, "Revisiting Karl Haushofer at 150," 42 n. 36. Karl Haushofer, "Einführung," in J. Fairgrieve, ed., Geographie und Weltmacht (Berlin, 1925), 1-11, at 6; Karl Haushofer, "Grundlage, Wesen und Ziele der Geopolitik," in Haushofer et al., Bausteine zur Geopolitik, 29-48, at 47-8; R. Sprengel, Kritik der Geopolitik (Berlin, 1996), 162.

${ }^{83}$ Haushofer's approach to mapping natural spaces onto cultural spaces, in order to bring the physicalmaterial with the cultural-aesthetic, to trace the deeper causes of fluctuations in human life forms in the traffic spaces across the oceans, compares and connects with Braudel. See Geoffrey Symcox, "Braudel and the Mediterranean City," in Gabriel Piterberg, Teofilo F. Ruiz, and Geoffrey Symcox, Braudel Revisited (Toronto, 2010), 35-52, at 37-8; Rolf Petri, "The Mediterranean Metaphor in Early Geopolitical Writings," History 101/348 (2016), 671-91.
} 
what Haushofer meant by the spatial concept, virtually all recent scholarship on the "Indo-Pacific" takes Haushofer for granted as a pale genealogical fact, with no effort to engage with his ideas. Readers of the "historical" geopolitical strategist of the Third Reich, on the other hand, are easily distracted by the salient contexts of the MolotovRibbentrop and the Tripartite Pacts. ${ }^{84}$ The risk herein is the failure to see Haushofer beyond his use of the notorious Lebensraum concept, his Kontinentalblock theory, or his alleged influences on Germany's Soviet and Japanese policy. As a result, scholars miss Haushofer's interwar vision for an "Indo-Pacific" coalition, headed by not only Japan but also India and China, against the maritime colonial powers of Western Europe, the British Empire, and the United States. Indeed, a serious analysis of Haushofer's "Indo-Pacific" is long overdue.

Haushofer's "Indo-Pacific" is a case where an intellectual intervention, motivated by the perceived geopolitical interest of a particular state, turns out to stimulate a global anticolonial vision beyond its immediate contexts. Taking past dictions and discourses on their own terms, I recover not only the product of Haushofer's spatial imaginations, but also the questions he raised along the way. As Haushofer realigned oceanic spaces to advance his political agenda, he engaged with multiple sets of perspectives in tension: the indigenous, settler, and colonial; the insular, coastal and oceanic; the Indic, Sinic, and "maritime nomadic"; the natural, social, and cultural; the local, stately, and international. As a result, the "Indo-Pacific" thesis is bewilderingly complex. Therefore it is all the more imprudent to gloss over Haushofer as simply "the first to use the term Indo-Pacific." Doing so inevitably projects the paler notion of "Indo-Pacific" as a site for great-power politics onto the richer idea in its dual contexts of political oceanography and anticolonial politics. Surely, if the past and present, life and afterlife of the "Indo-Pacific" are irrelevant to each other, then it is pointless to pinpoint Haushofer as a genealogical fact. If, however, the reincarnation of the "Indo-Pacific" hinges on, but fails to engage with, the critical insights of its original formulation-which I argue is the casethen it is imperative that political theorists and intellectual historians uncover the lost meanings for present deliberations. What is at stake is much more than anachronism. The neglect of what the "Indo-Pacific" was impoverishes our own political language. The result is a tremendous loss of intellectual richness, imaginative capacity, and conceptual complexity. Like today's "Indo-Pacific" advocates, Haushofer politicized marine ecology. But unlike political commentators today, Haushofer also interrogated colonial domination and self-determination, and how their tension maps onto the fault lines of landscapes and seascapes. Since Haushofer deployed politico-oceanographic evidence to legitimize anticolonial activism from within the region, the ideological foundation of the "Indo-Pacific" consists in the features, histories, and ideas emanating from its own vast space and various traditions. For all these reasons, probing Haushofer's theory is not a matter of

\footnotetext{
${ }^{84}$ Frank Ebeling, Geopolitik: Karl Haushofer und seine Raumwissenschaft 1919-1945 (Berlin, 1994); Henning Heske, "Karl Haushofer," Political Geography 6 (1987), 135-44; Gearóid Ó Tuathail, Simon Dalby, and Paul Routledge, The Geopolitics Reader (New York, 1998); David Thomas Murphy, The Heroic Earth (Kent, 1997); Trevor J. Barnes and Claudio Minca, "Nazi Spatial Theory," Annals of the Association of American Geographers 103/3 (2013), 669-87; Robert D. Kaplan, The Revenge of Geography (New York, 2012).
} 
antiquarian interest, but a substantive exercise of political reflections on the meanings, limits, and implications of the "Indo-Pacific" as a political language.

In this paper, I have suggested that despite the incredibly diverse building blocksmarine zoology, philology, and ethnography — at the oceanographic foundation of the "Indo-Pacific," Haushofer's case for the "Indo-Pacific" as one bloc, by natural and political necessity, suffers from serious flaws. In order to translate scientific evidence into political theory, Haushofer often skipped intermediary steps, glossed over arguments, and jumped to causal claims. Nevertheless, his rhetoric represents a unique mode of political reasoning in context, where his spatial determinism faced off rival determinisms, most notoriously "raciology" (Rassenkunde), a tradition based on a very different set of "natural-scientific" evidence. ${ }^{85}$ At a time when competing ideological trends were taking on the same perennial question in German political thought-the scarcity of strategic access to global "travel spaces"-Haushofer offered a global "belt-and-road" solution.

The "Indo-Pacific" strategy promotes the political resurrection of Asian peoples against "Euro-American" domination. The goal is not only to establish the "the fact of this uniform geopolitical mood ... in the Indo-pacific life space," but to explore its political potential. ${ }^{86}$ For this larger end, Haushofer built on his connections with not only Japan, but also South, East, and Southeast Asia, as pillars of the "Indo-Pacific" vision. However, repercussions fell flat in India, and reciprocations of Haushofer's interest in Chinese republicanism remained scant. Generations of scholars have noticed that only Japan witnessed a torrent of geo-oceano-political thinking, fueled in part by massive translations of Haushofer's works. ${ }^{87}$ Yet the primacy of Japan in Haushofer's reception should not obscure the balanced syncretism and syntheticism in the "Indo-Pacific" vision. Indeed, although "spatial determinism" is a common feature of German geopolitics, Haushofer sees spaces as polymorphic in his political oceanography. At a time when geographers challenge us to rethink the seemingly rock-solid divisions of continents, Haushofer's insistence on "polymorphic unity" provokes us to rethink the global oceanic space. ${ }^{88}$

\footnotetext{
${ }^{85}$ M. Bassin, "Race contra Space: The Conflict between German Geopolitik and National Socialism," Political Geography Quarterly 6/2 (1987), 115-34. Spang, Karl Haushofer und Japan, 266; Spang, "Revisiting Karl Haushofer at 150," 43.

${ }^{86}$ Haushofer, "Die Einheit der Monsunländer," 111, added emphasis.

${ }^{87}$ Kenneth W. Colegrove, "The New Order in East Asia," Far Eastern Quarterly 1/1 (1941), 5-24; Christian W. Spang, "Karl Haushofer und die Geopolitik in Japan," in Irene Diekmann, Julius Hans Schoeps, and Peter Krüger, eds., Geopolitik: Grenzgange im Zeitgeist (Potsdam, 2000), 591-629; C. W. Spang and R.-H. Wippich, eds., Japanese-German Relations, 1895-1945 (London and New York, 2006); Spang, Karl Haushofer und Japan; Ken Sato (佐藤健) “Nippon niokeru chiseigaku shisō no tenkai: senzen chiseigaku ni miru hōga to kikensei 日本における地政学思想の展開:戦前地政学に見る萌芽と危険 性,” in 北大法学研究科ジュニア・リサーチ・ジャーナル Junior Research Journal, Hokkaido University School of Law, vol. 11 (Hokkaido, 2005), 109-39.

${ }^{88}$ Martin W. Lewis and Kären Wigen, The Myth of Continents (Berkeley, 1997). The polymorphic conceptualization of maritime spaces remains a historiographical legacy. See Cornel Zwierlein, "Die Auswirkungen von spatial turn und Kulturtransferheuristiken auf das Epochenkonzept 'Frühe Neuzeit'," in Michael North, ed., Kultureller Austausch (Cologne, Weimar and Vienna, 2009), 43-67, at 45-8; Zwierlein, "Early Modern History," in Miram Dabag, Nikolas Jaspert, Achim Lichtenberger, and Dieter Haller, eds., Handbuch für Mediterranistik (Paderborn, 2015), 87-105, at 89; P. Tzermias, "Geography, Geopolitics and History: Considerations and Conclusions," Ekistics and the New Habitat 70/418-19 (2003), 42-6. Consider Paul Vidal de la Blache's polymorphic conception of the sea and Braudel's emphasis
} 
To conclude, the first step to regaining a richer "Indo-Pacific" theory is to examine its source, structure, and politics in historical contexts. The "Indo-Pacific" in interwar Germany was an integral oceanic space primed for political consciousness and positioned to undermine colonial domination. Out of Haushofer's historically specific arguments, the "Indo-Pacific" gave rise to global anticolonial visions. Indeed, it is in rethinking what the "Indo-Pacific" concept was that it becomes clear what has been lost, and what is to be regained, in its reincarnated life.

Acknowledgements. Versions of this paper have been presented at Yale MacMillan Center's European Studies Council, Columbia's Department of East Asian Languages and Cultures, Harvard's Political Theory Workshop, and the International Society in Global Context seminar. The author would like to thank the three anonymous referees and the coeditors of Modern Intellectual History, especially Tracie Matysik, for their critiques and comments, which transformed the article; Erez Manela and David Armitage for their guidance and counsel; Jeffry Frieden, Richard Tuck, Michael Rosen, Eric Beerbohm, Emma Rothschild, Arunabh Ghosh, Amelia Bonea, Priya Menon, Gene Kim, James Sojourner, Kwan Woo Hahn, Sarah Holzworth, Ivan Safranchuk, Joanna Lee, Katherine Irajpanah, Liya Nahusenay for conversations on this topic; and Christina Andriotis and Thom Wall for their generous support.

on the interrelation and interdependence of culture and environment, and how these approaches influence maritime, oceanic, and global histories up to the present day. My suggestion is that Haushofer's versatility already makes "possibilism" a possibility.

Cite this article: Li H (2022). The "Indo-Pacific": Intellectual Origins and International Visions in Global Contexts. Modern Intellectual History 19, 807-833. https://doi.org/10.1017/S1479244321000214 